\title{
Study of the Production of Lentinus crinitus (L.) Fr. Lignolytic Enzymes Grown on Agro-Industrial Waste
}

\author{
Taiana de Araújo Conceição¹, Maria Gabriela Bello Koblitz², Hélio Mitoshi Kamida3, \\ Aristóteles Góes-Neto 4 \\ ${ }^{1}$ Health Sciences Center, Universidade Federal do Recôncavo da Bahia, Santo Antonio de Jesus, Brazil \\ ${ }^{2}$ Food Technology Department, Universidade Federal do Estado do Rio de Janeiro, Rio de Janeiro, Brazil \\ ${ }^{3}$ Biological Sciences Department, Universidade Estadual de Feira de Santana, Feira de Santana, Brazil \\ ${ }^{4}$ Biological Sciences Institute, Universidade Federal de Minas Gerais, Belo Horizonte, Brazil \\ Email: taiana@ufrb.edu.br
}

How to cite this paper: Conceição, T.A. Koblitz, M.G.B., Kamida, H.M. and GóesNeto, A. (2017) Study of the Production of Lentinus crinitus (L.) Fr. Lignolytic Enzymes Grown on Agro-Industrial Waste. Advances in Bioscience and Biotechnology, 8, 259-272. https://doi.org/10.4236/abb.2017.88019

Received: July 19, 2017

Accepted: August 19, 2017

Published: August 22, 2017

Copyright (c) 2017 by authors and Scientific Research Publishing Inc. This work is licensed under the Creative Commons Attribution International License (CC BY 4.0).

http://creativecommons.org/licenses/by/4.0/

\begin{abstract}
Exclusively Brazilian, the Caatinga biome has been thus far a place of very few studies on the Basidiomycetes fungi. Due to its semiarid climate, fungi found in the region are likely to carry lignolytic enzymes which hold biotechnological potential to be used in industrial processes of agro-industrial residue bioconversion. This study performed a response surface statistical planning to optimize the secretion of enzymes such as laccase (Lac), lignin peroxidase (LiP) and manganese peroxidase (MnP) by Lentinus crinitus. Three variables were under analysis: different concentrations of barley and cassava residue, $\mathrm{pH}$ and temperature. MnP enzyme showed the highest enzymatic activity rate (23.5 IU/L). Additionally, $\mathrm{MnP}$ had the best results of enzyme secretion for substrate composition of $50 \%$ barley and $50 \%$ cassava, at $\mathrm{pH} 7$ and temperature at $28^{\circ} \mathrm{C}$ for a 28-day incubation period. However, further studies are pivotal to test the efficiency in lignin bioconversion by the enzymes synthesized in this work and also to establish their usage pattern on a large scale.
\end{abstract}

\section{Keywords}

Lignolytic Enzymes; Lentinus, Agro Waste

\section{Introduction}

Brazilian Northeast region presents wide climate variations, from humid to semiarid. Caatinga, an exclusive Brazilian biome, corresponds basically to the semiarid region, which is hot and dry. The semiarid has an average annual tem- 
perature of about $25.5^{\circ} \mathrm{C}$, and is known for its short rainy season (a 3 to 5-month period), long dry season (which takes 7 to 9 months) and irregular rainfall distribution over time and area. Góes-Neto et al. [1], after carrying researches on lignolytic Aphyllophorales fungi in Serra da Jibóia, a humid forest area in the semiarid in Bahia State, observed that both Caatinga and Mata Atlântica territory may be similar in biodiversity. Incidentally, most taxa records are from that state, totaling 54. The semiarid and Caatinga, in comparison to other regions and biomes, are less studied in relation to the number of researches done and published on Agaricomycetes diversity [2].

The Agaricomycetes comprise every Basidiomycota that form basidiomes with definite hymenium [3]. Most Agaricomycetes species can cause wood decay (by lignin or cellulose or both and hemicellulose hydrolysis). These species are called lignolytic or lignocellulolytic, and they may be divided into three groups, according to the decay morphology: white-rot, brown-rot or soft-rot fungi [2] [4].

Extracellular phenoloxidase activity, suggesting presence of lignolytic enzymes, was discovered in the 1930's in white-rot fungi [5], and subsequently it was proven that the reactions were catalyzed by oxidoreductase of both laccase and peroxidase type [6]. Capacity for oxidizing specifically phenolic compounds has been used as an identification criterion for actual white-rot fungi [7]. After laccase (Lac) isolation, other peroxidases named as lignin peroxidase (LiP) and manganese peroxidase ( $\mathrm{MnP})$ were evidenced in lignin breakdown [8] [9].

Both MnPs and LiPs are glycoproteins which seem to be the most ubiquitous lignolytic enzyme group among the white-rot fungi. The former enzyme group has about fifteen different isolated isoforms and relates closely to the latter, since it oxidizes $\mathrm{Mn}^{2+}$ and $\mathrm{Mn}^{3+}$, whose cations may oxidize phenolic units of lignin and may also take part in phenolic fragmentation [10] [11]. A third enzyme, laccase (Lac), has been drawing considerable attention for ten years due to its role in lignin decay and potential contribution in detoxification of phenolic pollutants [12] [13] [14] [15] [16]. Over the last decades there has been an increasing search for agro-industrial residue usage owing, to a progressive demand of the agricultural activities. Accumulation of these residues may deteriorate the environment and destroy resources, contributing significantly to recycling problems and biomass conservation. Several projects utilizing these materials have been developed. They transform the agro-industrial residue in chemical compounds and products of high added value. Lignocellulosic residues are also an excellent alternative for energy generation due to its availability in the environment. The usage of agricultural residue as substrate in bioprocesses, in addition to being cost-effective, minimizes environmental problems related to such residue accumulation [17] [18] [19].

Response surface methodology (RSM) is a collection of mathematical and statistical techniques for empirical model building. By careful design of experiments, the objective is to optimize a response which is influenced by several independent variables. An experiment is a series of tests, called runs, in which changes are made in the input variables in order to identify the reasons for changes in the 
output response. The main characteristic of this approach was that it took into account the heterogeneity of the variances of the responses and also the correlated nature of the responses. Mathematical models have been increasingly used to help explain responses of biochemical reactions. In many cases, the interaction of parameters influencing fermentative processes can be evaluated with a reduced number of trials through experimental planning. In relation to the lytic enzymes, the response surface methodology is frequently used for the optimization and verification of the influence of the components of the culture medium for the production of the enzymes, as well as for the optimization and the verification of the influence of parameters in the enzymatic production [20] [21] [22].

The aim of this work was to study the secretion of lignolytic enzymes (laccase, manganese peroxidase and lignin peroxidase) by an agaricomycete fungus collected in the semi-arid region of the state of Bahia, Brazil, through solid state fermentation using agro industrial waste generated in the state and perform the partial biochemical characterization of the enzymatic activity obtained.

\section{Materials and Methods}

\subsection{Collection and Identification}

Thirty unidentified fungi isolates were tested for their ability to decolorize Remazol Brilliant Blue R (RBBR) dye in Petri dishes containing agar and the dye, according to methodology described by Kamida et al. [4]. The L. crinitus isolate showed the larger decolorization halo in a short period of time and was thus selected for identification and further studies (data not shown).

The fungal strain was collected on Cachoeira Jajai trail of Sete Passagens State Park, in Miguel Calmon, Bahia, at coordinates 13 $39^{\prime} 46^{\prime \prime S}$ and 39 $19^{\prime} 39^{\prime \prime} \mathrm{W}$. Isolation was carried out using both, the pieces of the basidiome which were not in contact with the air, and the spore to grow in potato dextrose agar medium supplemented with yeast extract [23] and continuous transplants were made to preserve the lineage. The fungus was deposited at the Culture Collection of Microorganisms of Bahia (CCMB UEFS), identification number CCMB 553 (http://www.uefs.br/ccmb).

The DNA of this species was extracted from the mycelium grown for about 20 days according to [24]. The ITS 1 and ITS4 primers were used, which correspond to the proposed regions as DNA barcoding for fungi. The PCR reaction was performed in 28 cycles $\left(94^{\circ} \mathrm{C}-4\right.$ min., $94^{\circ} \mathrm{C}-1$ min., $50^{\circ} \mathrm{C}-1$ min., $72^{\circ} \mathrm{C}-3$ min., and $72^{\circ} \mathrm{C}-7 \mathrm{~min}$.). The PCR products were purified by digestion with alkaline phosphatase and exonuclease (kit ExoSap IT, GE). The sequencing reaction was performed with Big Dye Terminator version 3.1 (Applied Biosystems). The sample was sequenced in both directions using the automatic sequencer SCE 2410 (Spectrumedix LLC) in the Molecular Laboratory of the State University of Feira de Santana (UEFS). The resulting electropherogram was edited by using the GAP4 program of the Staden Package [25]. The resulting sequence was submitted to research at BLASTn from NCBI (National Center for Biotechnology Information-http://www.ncbi.nlm.nih.gov), aligned using the program Clu- 
stral X [26] and manually adjusted. The sequence was deposited at GenBank (NCBI) under number KR014256. After the molecular indication, the field data were reviewed [2] and compared with the species description in MycoBank for validation.

\subsection{Culture Conditions Optimization}

A multivariate experimental design was used through the application of the software Statistica (6.0), in which the program generated test sheets and the response surfaces. The following independent variables were analyzed: lignocellulosic substrate type, incubation temperature and initial $\mathrm{pH}$ of the medium, according to the parameters of Table 1 . The activity of Lac, MnP and LiP secreted was evaluated as the response (dependent variable), as the following description. The enzyme extract produced in each assay was obtained by the addition of distilled water to the vials, homogenization and filtering in a synthetic filter. The filtrate was centrifuged at $13,000 \mathrm{rpm}$ at $4^{\circ} \mathrm{C}$ for 10 minutes and the supernatant used for analysis. In order to elaborate the control, aliquots of each obtained extract were treated at $100^{\circ} \mathrm{C}$ for 10 minutes for complete inactivation of the enzymatic activity.

\subsection{Enzymatic Activity Evaluation}

The activity of the enzyme Laccase was determined by the transformation of the Syringaldazine as an enzymatic substrate for 10 minutes at $525 \mathrm{~nm}$ [27]. The activity of Manganese Peroxidase was determined by the oxidation of phenol red in the presence of hydrogen peroxide at 610nm [9]. The activity of Lignin Peroxidase was determined by the oxidation of veratryl alcohol at $310 \mathrm{~nm}$ [8].

Calculation of enzymatic activity devises the following Equation (1):

$$
\text { EnzymeIU } / L=\frac{\Delta A \times 10^{6}}{€ \times R \times T}
$$

where $\Delta \mathrm{A}$ is the absorbance variation; $10^{6}$ is the correction factor; $€$ is the extinction coefficient; $\mathrm{R}$ is the volume of the enzymatic extract; and $\mathrm{T}$ is the time of reaction.

After the determination of the best culture conditions for secretion of the enzymes, the influence of the incubation time under the recommended conditions was evaluated. The enzymatic activity was evaluated at six different incubation times: 4, 7, 14, 21, 28 and 35 days of fungus growth in conical flasks $(250 \mathrm{~mL})$ containing $5 \mathrm{~g}$ of each waste, at $90 \%$ moisture content and incubated at $20^{\circ} \mathrm{C}$ in a

Table 1. Statistical planning.

\begin{tabular}{cccccc}
\hline Variable & $-\boldsymbol{\alpha}(1.68)$ & -1 & 0 & +1 & $+\boldsymbol{\alpha}(1.68)$ \\
\hline Substrate: ${ }^{1}$ barley ${ }^{2}$ cassava & $0^{1}: 100^{2}$ & $30^{1}: 70^{2}$ & $50^{1}: 50^{2}$ & $80^{1}: 20^{2}$ & $100^{1}: 0^{2}$ \\
$\mathrm{pH}$ & 3.0 & 4.62 & 7.0 & 9.38 & 11.0 \\
Temperature & 20 & 23.2 & 28 & 32.8 & 36 \\
\hline
\end{tabular}


BOD. The cultivation was conducted in triplicate and the enzyme activity was evaluated in triplicate.

\subsection{Effects of pH on the Enzymatic Activity}

The $\mathrm{pH}$ effect was evaluated by its variation in the reaction medium and by determining the enzymes activity in the medium under exposure to the 10 different values of $\mathrm{pH}: 3,4,4.5,5,6,7,8,9,10$, and 11 .

\subsection{Effects of Temperature on the Enzymatic Activity}

The temperature effect was evaluated by its variation of the reaction medium and by determining the enzymatic activity after exposure to 8 temperature values: $20^{\circ} \mathrm{C}$, $30^{\circ} \mathrm{C}, 40^{\circ} \mathrm{C}, 50^{\circ} \mathrm{C}, 60^{\circ} \mathrm{C}, 70^{\circ} \mathrm{C}, 80^{\circ} \mathrm{C}$ and $90^{\circ} \mathrm{C}$.

\section{Results and Discussion}

\subsection{Identification}

PCR amplification of the ITS region of the lineage with the ITS 1 and ITS 4 primers resulted in characteristic fragments of approximately $600 \mathrm{bp}$, as demonstrated by literature [28]. Molecular analysis showed that the lineage had $94 \%$ of identity with Lentinus crinitus with $100 \%$ coverage (Figure 1). ITS is recognized as a fungal Barcode because it is the most sequenced region of fungi and is routinely used for systematics, phylogenetics, and identification [29]. The identification found on the Blast platform was also confirmed by comparing it with the

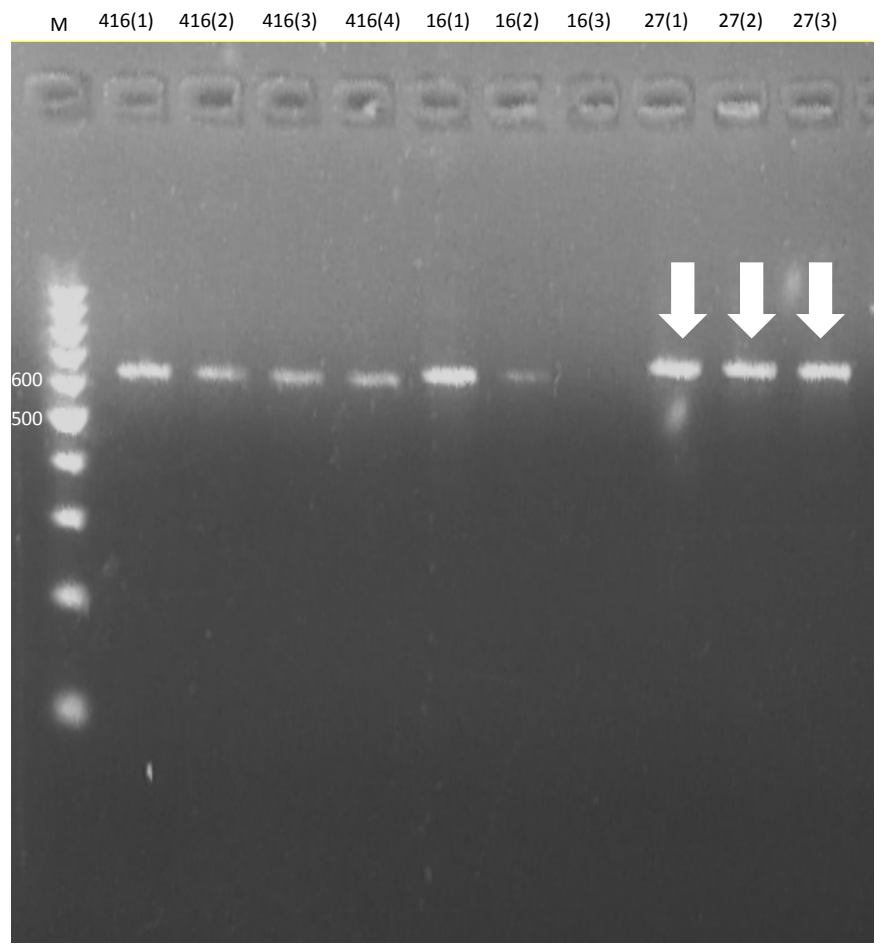

Figure 1. Gel electrophoresis of the PCR product. The fragment of $600 \mathrm{bp}$ is shown by the arrow in the lane with number 27. Size marker in base pairs (M). 
macroscopic characteristics of the field data, such as the surface and shape of the pileus.

\subsection{Optimization and Enzymatic Activity}

The analysis of variance for the enzymes tested wasn't significant for LiP in which the $F$ value (1.39) was less than $F_{\text {tab }}$ (3.68), with coefficient $R^{2}(0.64)$ at $5 \%$ and this data could not be approved for evaluation. The analysis for Lac was also not significant, with $\mathrm{F}$ value (1.2) less than $\mathrm{F}_{\text {tab }}(3.68)$ at $5 \%$, with coefficient $\left(\mathrm{R}^{2}\right.$ $=0.60)$, but in this specific case, however, the lack of adjustment was significant (69.60), indicating that there may have been significant difference between the results obtained, but the surface generated by the software was not a good description of the generated data. The only enzyme that showed valid variance was the $\mathrm{MnP}$, with $\mathrm{F}$ value (15.23) higher than $\mathrm{F}_{\text {tab }}(6.72)$ with coefficient $\left(\mathrm{R}^{2}=0.95\right)$. These results were statistically significant at a $1 \%$ level meaning that there was a good correlation between the activities determined experimentally and the values predicted by the model (Equation (2)), since $95 \%$ of the variability in the experimental data could be explained by the estimated model. The secretion of manganese peroxidase proved to be dependent on the substrate, $\mathrm{pH}$ and temperature factors, but not from their interactions as seen in the Pareto Diagram (Figure 2). The analysis of the response surfaces obtained from the quadratic model among the variables showed that the best secretion conditions of the manganese peroxidase enzyme of $L$. crinitus were those with an equal percentage of substrate, medium temperature and neutral $\mathrm{pH}$ (Figure 3), where the enzyme activity value of $23.59 \mathrm{U} / \mathrm{L}$ was obtained. This results support the hypothesis raised by Manpreet et al. [30] that most of basidiomycete fungi best grows in the temperature range of $20^{\circ} \mathrm{C}$ to $30^{\circ} \mathrm{C}$ and that the temperature control of fungal

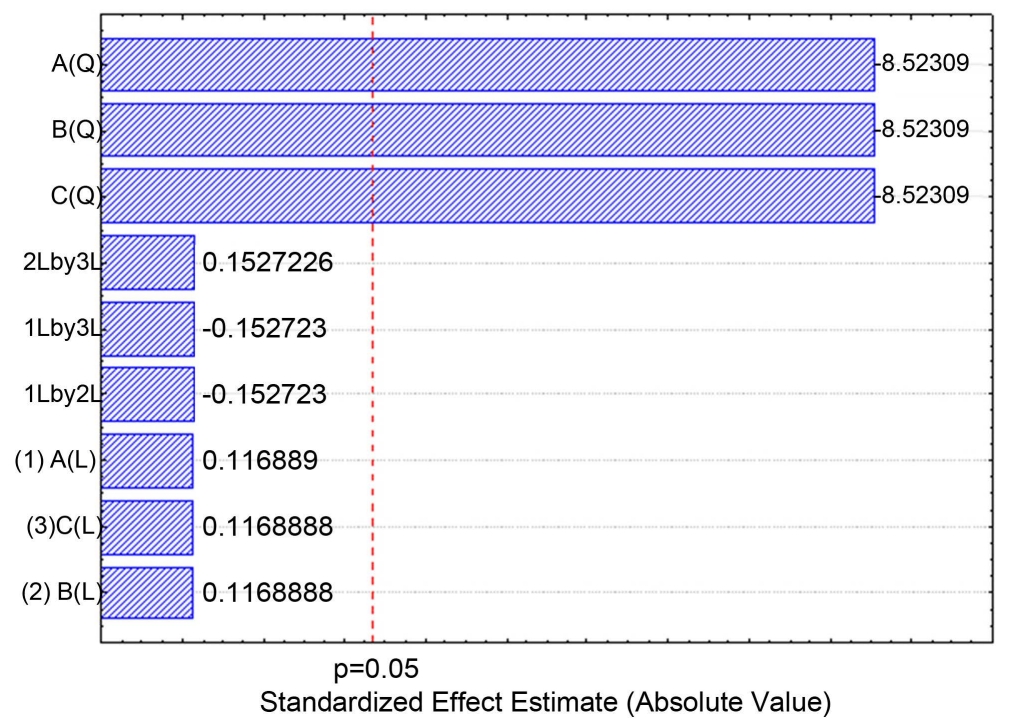

Figure 2. Pareto graph showing the effect of substrate (A), $\mathrm{pH}(\mathrm{B})$ and temperature $(\mathrm{C})$ as well as their interactions on $\mathrm{MnP}$ production of L. crinitus. 

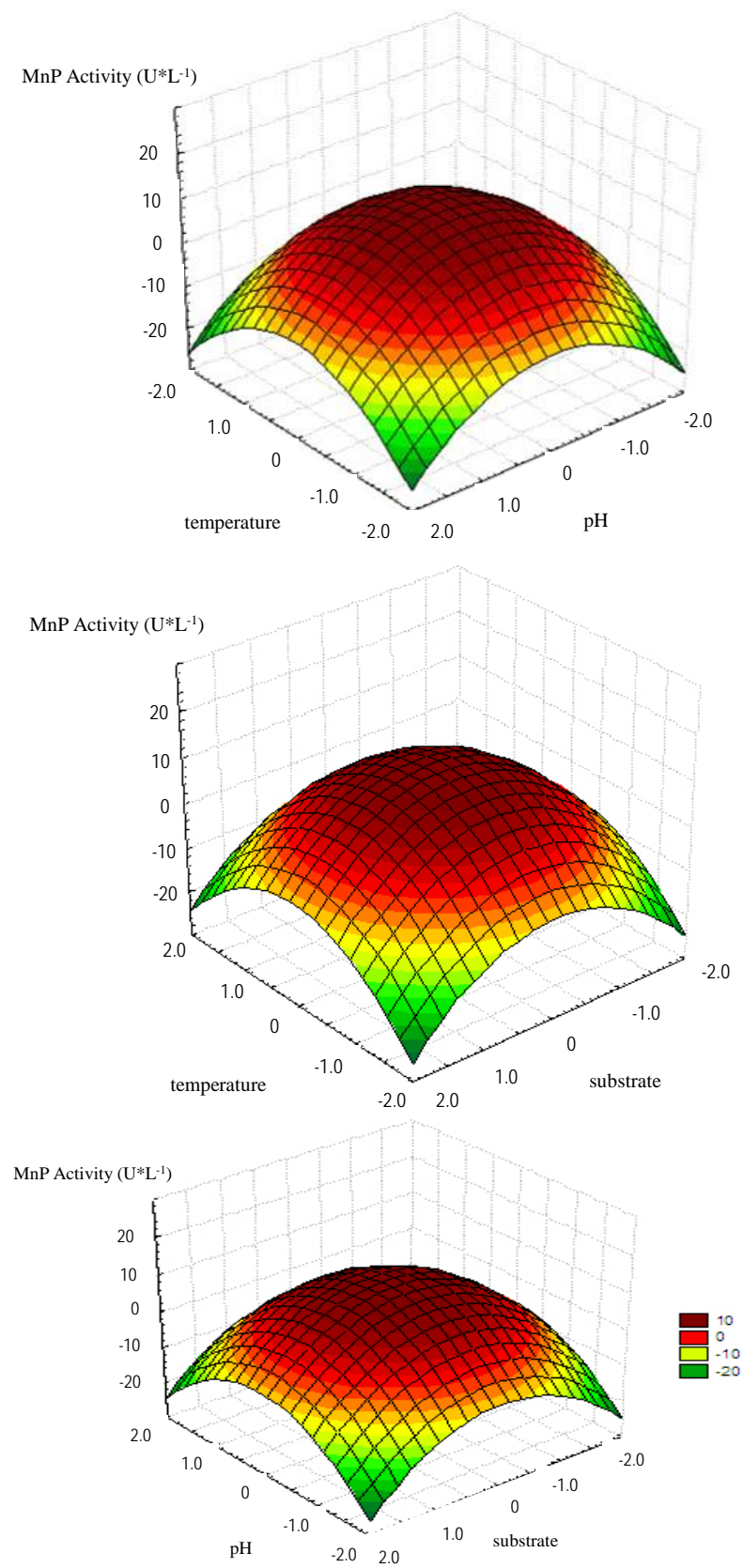

Figure 3. Response surfaces for influence of substrate, $\mathrm{pH}$ and temperature on $\mathrm{MnP}$ activity.

development is a key factor in the regulation of solid state fermentation to optimize delignification processes.

$$
y=6.108126-0.000408 A^{2}-0.014337 B^{2}-0.0007772 C^{2}
$$

where: $\mathrm{A}$ is the $\%$ of substrate content, $\mathrm{B}$ is the initial $\mathrm{pH}$ value and $\mathrm{C}$ is the temperature of incubation.

The activity value found was similar to that of [31] found for this genus (30 U/L) using landfill slurry as substrate; and superior than that of [32] for Pleurotus using sawdust and wheat bran $(8.1 \mathrm{U} / \mathrm{mL})$. For the species in medium with 
low nitrogen content a higher value of activity ( $60 \mathrm{U} / \mathrm{L})$ was verified [15]. However, much lower values were found for other species of the genus when submitted to solid fermentation in wheat bran and rice bran [33]. When compared to the solid fermentation of other fungi of white-rot in diverse substrates, the value obtained in the present work was superior. In all the researched references, the activity of the $\mathrm{MnP}$ enzyme is verified for some species of the genus Lentinus. The different results found for different substrate types in several studies indicate that the substrate is an important factor in MnP secretion (Table 2). The production of the extracellular lignolytic enzymes is strongly affected by the nature and amount of the nutrients in the substrate; however the data about strict effect of available sources in the substrate on extracellular lignolytic enzyme induction in wood-rotting basidiomycetes have been conflicting. For some species, the lignolytic enzyme production is suppressed by high nitrogen concentration while for other, high concentration of this nutrient stimulate ligninase production, being thus strain dependent. Besides the nature of lignocellulosic material, the method of fungi cultivation, including important factors like temperature, humidity and $\mathrm{pH}$ are determinant for the expression of lignolytic potential of fungi [33] [34] [35].

Table 2. Enzymatic activity of Basidiomycota fungi found in published studies.

\begin{tabular}{|c|c|c|c|}
\hline Source & Lineage & Substrate & MnP Activity \\
\hline [31] & L. tigrinus & Landfill slurry & $30 \mathrm{U} / \mathrm{L}$ \\
\hline [15] & L. tigrinus & Malt extract and glucose & $60 \mathrm{U} / \mathrm{L}$ \\
\hline \multirow{6}{*}{ [33] } & Lentinus sp. & \multirow{3}{*}{ Wheabran } & $8 \mathrm{U} / \mathrm{mL}$ \\
\hline & L. strigellus & & $2 \mathrm{U} / \mathrm{mL}$ \\
\hline & $\begin{array}{l}\text { Pycnoporus san- } \\
\text { guineus }\end{array}$ & & $2 \mathrm{U} / \mathrm{mL}$ \\
\hline & Lentinus sp. & \multirow{3}{*}{ Rice bran } & \\
\hline & L. strigellus & & $0.5 \mathrm{U} / \mathrm{mL}$ \\
\hline & P. sanguineus & & $0.6 \mathrm{U} / \mathrm{mL}$ \\
\hline [34] & White rot & Wheat bran & $0.5 \mathrm{U} / \mathrm{mL}$ \\
\hline \multirow{6}{*}{ [13] } & \multirow{6}{*}{ White rot } & Tangerine bagasse & $2.3 \mathrm{U} / \mathrm{mL}$ \\
\hline & & Wheat bran & $1.4 \mathrm{U} / \mathrm{mL}$ \\
\hline & & Banana peel & $3.1 \mathrm{U} / \mathrm{mL}$ \\
\hline & & Kiwi peel & $6.7 \mathrm{U} / \mathrm{mL}$ \\
\hline & & Walnut leaf & $1.3 \mathrm{U} / \mathrm{mL}$ \\
\hline & & Nut pericarp & $8.3 \mathrm{U} / \mathrm{mL}$ \\
\hline [31] & Pleurotus eryngii & Sawdust with wheat bran & $8.1 \mathrm{U} / \mathrm{mL}$ \\
\hline [36] & Corioulos versicolor & Sweet sorghum bagasse & $8.1 \mathrm{Ug}^{-1}$ \\
\hline [37] & Pleurotos sapidus & Rice and wheat bran & $59.2 \mathrm{U} / \mathrm{mL}$ \\
\hline [38] & Trametes versicolor & Wheat bran & $1.75 \mathrm{U} / \mathrm{mL}$ \\
\hline
\end{tabular}




\subsection{Influence of Incubation Time}

According to the graph of Figure 4, an increase of the specific activity was observed until the 28th day, after which it decreased until reaching half on the highest value on the 35th day. The analysis of variance with Tukey's test for comparison of means was applied for all times, with a significant statistical difference between them at a significance level of 5\%. Therefore, 28 days of incubation was considered the best time for $\mathrm{MnP}$ secretion under the conditions of cultures optimized for L. crinitus. That peak of production of lignolytic enzymes in the $28^{\text {th }}$ day was also found by Thiribhuvanamala et al. [35] for Pleurotus sajor-caju grown on different agro wastes, not only for MnP, but also for Lac and LiP. The same result was also found by Dini [34] for Phlebia rufa and Bjerkandera adusta grown on wheat straw. Available studies about MnP activity for other species of Lentinus like L. strigellus [33] and L. tigrinus [15] show increasing MnP activity around the $3^{\text {rd }}$ week. This show that L. crinitus exhibits MnP activity peak after similar cultivation time to other white rot species.

\subsection{Effect of pH on the Enzymatic Activity}

The experiment was carried out to determine the optimum $\mathrm{pH}$ of enzyme activity by varying the $\mathrm{pH}$ of the reaction medium. The MnP of $L$. crinitus obtained under optimized conditions of 50\% barley and 50\% cassava substrate with $90 \%$ moisture at $\mathrm{pH} 7$ and incubated for 28 days at $28^{\circ} \mathrm{C}$ performed well over a large $\mathrm{pH}$ range, which varied from 4 to 8 , decreasing abruptly after that value. The best verified activity was at pH 5 with $18.65 \mathrm{U} / \mathrm{L}$ as shown in Figure 5 . The wide spectrum of $\mathrm{pH}$ performance verified in this enzyme differs from other studies such as that of [39]. In this work, the white-rot fungi generally presented MnP activity at more acidic $\mathrm{pH}$ ranging from 2.6 to 4.5 . The wide range of action may be due to the presence of several isoforms in the enzymatic extract and indicates

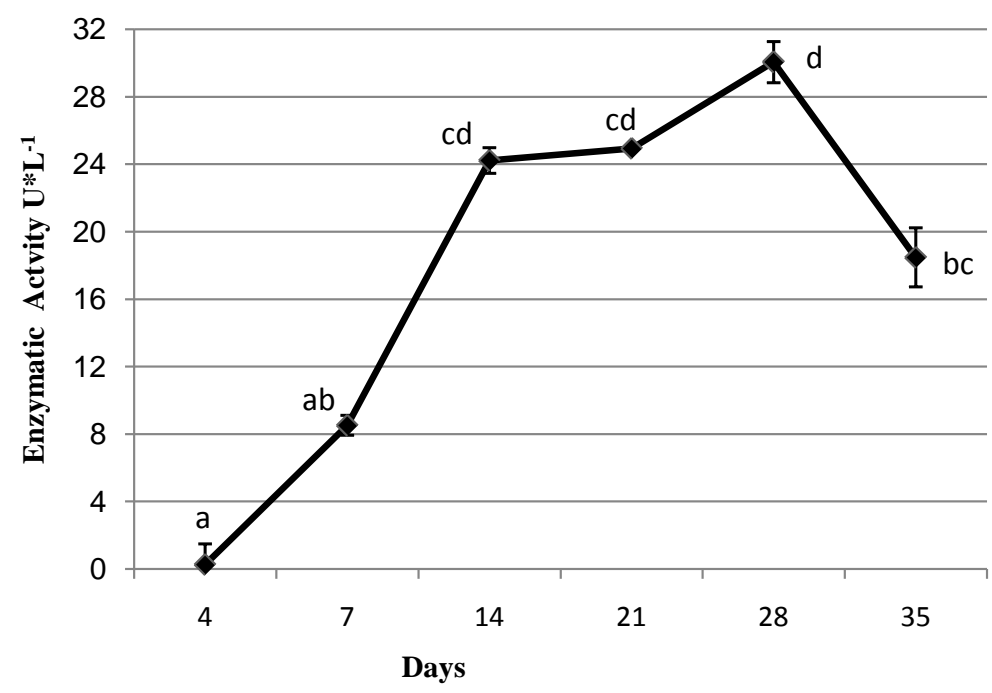

Figure 4. Time course graph of MnP secretion. The mean values with the same letters do not differ among themselves according to the Tukey test. 
that this enzyme could be advantageous for use in industrial processes.

\subsection{Effect of Temperature on the Activity}

Having determined the optimum activity $\mathrm{pH}$, the $\mathrm{pH}$ of the reaction medium was set at 5 and the enzymatic activity was determined by varying the temperature of the reaction medium. The highest activity rate was observed at the temperature of $40^{\circ} \mathrm{C}$ with $28.97 \mathrm{U} / \mathrm{L}$ (Figure 6), similar to the result found by other study [33] in which was found this same temperature value for another species of the same genus (L. strigellus). The same researchers found an optimum temperature of activity around $50^{\circ} \mathrm{C}$ for another species of Lentinus. As observed for the $\mathrm{pH}$ results, the $\mathrm{MnP}$ enzyme also showed activity over a wide temperature range (between $20^{\circ} \mathrm{C}$ and $50^{\circ} \mathrm{C}$ ).

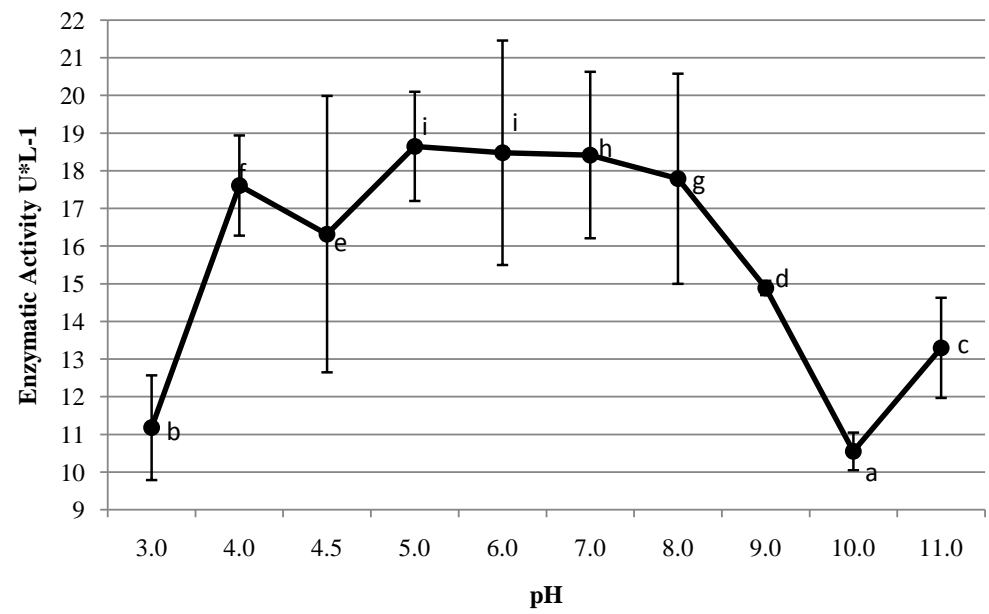

Figure 5. Enzymatic activity of $\mathrm{MnP}$ at different $\mathrm{pH}$ values. The mean values with the same letters do not differ among themselves according to the Tukey test.

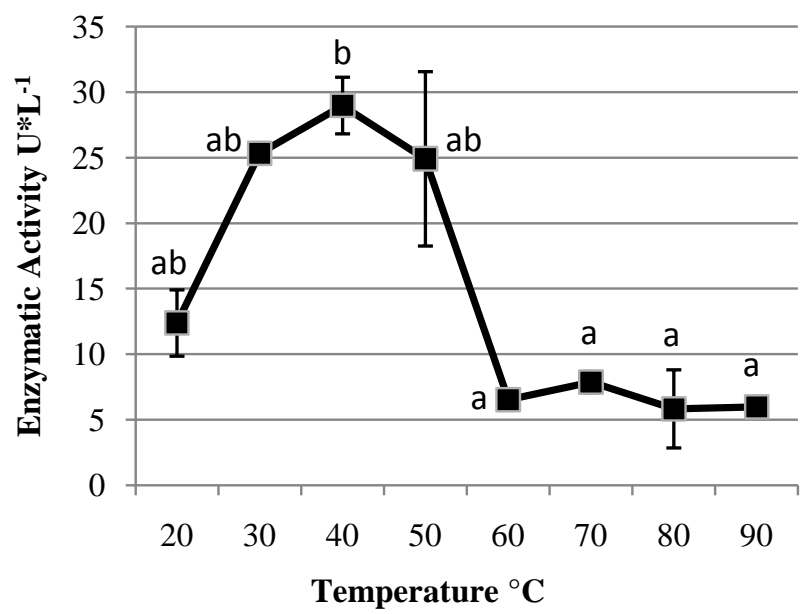

Figure 6. Enzymatic activity of $\mathrm{MnP}$ at different temperatures values. The mean values with the same letters do not differ among themselves according to the Tukey test. 


\section{Conclusions}

Agaricomycetes s.l. belong to a group present in several regions of the state of Bahia, but it is still little inventoried, thus further studies on this subject are extremely important.

The culture conditions tested for $L$. crinitus were not favorable for the production of Lac and LiP, other studies to determine the production parameters should be developed. The best enzyme secretion result was to $\mathrm{MnP}$ in the substrate composition with $50 \%$ barley and $50 \%$ cassava, $\mathrm{pH} 7$ at a temperature of $28^{\circ} \mathrm{C}$ and for a 28 -day incubation period. The L. crinitus $\mathrm{MnP}$ enzyme secreted in these conditions shows its best activity results at $\mathrm{pH} 5$ and temperature of $40^{\circ} \mathrm{C}$, and is also active in a wide range of $\mathrm{pH}$ and temperature.

The large amplitude of activity observed for $\mathrm{MnP}$ of $L$. crinitus in different values of $\mathrm{pH}$ and temperature demonstrates a high biotechnological potential and possible applicability of this enzyme by the industry.

The tested lineage showed to be dependent on the factors: substrate, humidity, $\mathrm{pH}$, temperature and incubation time for enzyme production. The agro-industrial residues of barley and cassava used are appropriate substrates for the production of lignolytic enzymes as observed in the obtained results. It demonstrates a new approach to recycling these residues that are abundant in the region and constitute a serious environmental problem.

Further studies are needed to test the efficiency in the bioconversion of lignin by the enzymes produced in the present work, as well as to develop standards of large-scale use of these enzymes.

\section{Acknowledgements}

The authors thank Fundação de Amparo à Pesquisa of the State of Bahia for the master's degree grant.

\section{References}

[1] Goes-Neto, A., et al. (2003) Lignicolous Aphyllophoroid Basidiomycota in an Atlantic Forest Fragment in the Semi-Arid Caatinga Region of Brazil. Mycotaxon, 88, 359-364.

[2] Santos, E.R.D. (2010) Diversity of lignolytic Agarycomycetes in the Brazilian Semi-Arid. Ph.D. Thesis, Universidade Federal de Pernambuco, Recife.

[3] Hibbett, D.S., et al. (2007) A Higher-Level Phylogenetic Classification of the Fungi. Mycological Research, 111, 509-547. https://doi.org/10.1016/j.mycres.2007.03.004

[4] Kamida, H.M., et al. (2005) Decolourization of Municipal Effluent and Sludge by Pleurotus sajor-caju and Pleurotus ostreatus. World Journal of Microbiology \& Biotechnology, 21, 1363-1369. https://doi.org/10.1007/s11274-005-5143-y

[5] Eriksson, K.E.L. (1990) Biotechnology in the Pulp and Paper Industry. Wood Science and Technology, 24, 79-101. https://doi.org/10.1007/BF00225309

[6] Hofrichter, M., et al. (2010) New and Classic Families of Secreted Fungal Heme Peroxidases. Applied Microbiology and Biotechnology, 87, 871-897.

https://doi.org/10.1007/s00253-010-2633-0 
[7] Käärik, A. (1965) The Identification on the Mycelia of Wood Decay Fungi by Their Oxidation Reaction with Phenolic Compounds. Studia Florestalia Suecia, 31, 1-80.

[8] Tien, M. and Kirk, T.K. (1984) Lignin-Degrading Enzyme from Phanerochaete chrysosporium: Purification, Characterization and Catalytic Properties of a Unique $\mathrm{H}_{2} \mathrm{O}_{2}$ Requiring Oxygenase. Proceeding of the National Academy of Science, 81, 2280-2284. https://doi.org/10.1073/pnas.81.8.2280

[9] Kuwahara, M., et al. (1984) Separation and Characterization of Two Extracellular $\mathrm{H}_{2} \mathrm{O}_{2}$ Dependent Oxidases from Lignolytic Cultures of Phanerochaete chrysosporium. FEBS Letters, 169, 247-250. https://doi.org/10.1016/0014-5793(84)80327-0

[10] Morgenstern, I., et al. (2008) Molecular Evolution and Diversity of Lignin Degrading Heme Peroxidases in the Agaricomycetes. Journal of Molecular Evolution, 66, 243-257. https://doi.org/10.1007/s00239-008-9079-3

[11] Xu, H., et al. (2017) Expression and Characteristics of Manganese Peroxidase from Ganoderma Lucidum in Pichia pastoris and Its Application in the Degradation of Four Dyes and Phenol. BMC Biotechnology, 17, 1-12. https://doi.org/10.1186/s12896-017-0338-5

[12] Kadimaliev, D.A., et al. (2008) Increased Secretion of Lignolytic Enzymes by the Lentinus crinitus Fungus after Addition of Butanol and Toluene in Submerged Cultivation. Applied Biochemistry and Microbiology, 44, 528-534. https://doi.org/10.1134/S000368380805013X

[13] Elisashvili, V. and KACHLISHVILI, E. (2009) Physiological Regulation of Laccase and Manganese Peroxidase Production by White-Rot Basidiomycetes. Journal of Biotechnology, 144, 37-42. https://doi.org/10.1016/j.jbiotec.2009.06.020

[14] Hadibarata, T., et al. (2009) Biodegradation of Chrysene, an Aromatic Hydrocarbon by Polyporus sp. S133 in Liquid Medium. Journal of Hazardous Materials, 164, 911917. https://doi.org/10.1016/j.jhazmat.2008.08.081

[15] Covino, S., et al. (2010) In Vivo and in Vitro Polycyclic Aromatic Hydrocarbons Degradation by Lentinus (Panus) crinitus CBS 577.79. Bioresource Technology, 101, 3004-3012. https://doi.org/10.1016/j.biortech.2009.12.020

[16] Elisashvili, V., et al. (2010) Effect of Aromatic Compounds on the Production of Laccase and Manganese Peroxidase by White-Rot Basidiomycetes. The Journal of Industrial Microbiology and Biotechnology, 37, 1091-1096. https://doi.org/10.1007/s10295-010-0757-y

[17] Alexandrino, A.M., et al. (2007) Reutilization of Orange Waste for Production of Lignocellulolytic Enzymes by Pleurotus ostreatus (Jack: Fr). Ciência e Tecnologia de Alimentos, 27, 364-368. https://doi.org/10.1590/S0101-20612007000200026

[18] Menezes, C.R., et al. (2009) Sugarcane Bagasse: Source for the Production of Ligninocelullolytic Enzymes. Estudos Tecnológicos, 5, 68-78.

https://doi.org/10.4013/ete.2009.51.05

[19] Bilal, M., et al. (2017) Biotransformation of Lignocellulosic Materials into ValueAdded Products-A Review. International Journal of Biological Macromolecules, 98, 447-458. https://doi.org/10.1016/j.ijbiomac.2017.01.133

[20] Fleuri, L.F. and Sato, H.H. (2008) Study of Different Parameters in the Production of Lytic Enzymes. Food Science and Technology, 28, 299-310. https://doi.org/10.1590/S0101-20612008000200006

[21] Aanchal, et al. (2016) Response Surface Methodology for Optimization of Microbial Cellulase Production. Romanian Biotechnological Letters, 21, 11832-11841.

[22] Morshedi, A. and Akbarian, M. (2014) Application of Response Surface Methodol- 
ogy: Design of Experiments and Optimization: A Mini Review. Indian Journal of Fundamental and Applied Life Sciences, 4, 2434-2439.

[23] Oss, O.T. and Oeric, O.N. (1986) Psilocybin, Magic Mushroom Growers Guide. Lux Natura, Quick American Archives, San Francisco.

[24] Góes-Neto, A., et al. (2005) DNA Extraction from Frozen Field Collected and Dehydrated Herbarium Fungal Basidiomata: Perform of SDS and CTAB Based Methods. Biotemas, 18, 19-32.

[25] Staden, R., et al. (1998) The Staden Package. Methods in Molecular Biology, 132, 115-130.

[26] Thompson, J.D., et al. (1997) The CLUSTAL_X Windows Interface: Flexible Strategies for Multiple Sequence Alignment Aided by Quality Analysis Tools. Nucleic Acids Research, 25, 4876-4882. https://doi.org/10.1093/nar/25.24.4876

[27] Szklarz, G., et al. (1984) Production of Phenoloxidases and Peroxidases by WoodRotting Fungi. Mycologia, 81, 234-240. https://doi.org/10.2307/3759705

[28] Schmidt, O. and Moreth, U. (2003) Data Bank of rDNA-ITS Sequences from Building-Rot Fungi for Their Identification. Wood Science of Technology, 37, 161-163. https://doi.org/10.1007/s00226-003-0162-Z

[29] Badotti, K., et al. (2017) Effectiveness of ITS and Sub-Regions as DNA Barcode Markers for the Identification of Basidiomycota (Fungi). BMC Microbiology, 17-42.

[30] Manpreet, S., et al. (2005) Influence of Process Parameters on the Production of Metabolites in Solid-State Fermentation. Malalaysian Journal of Microbiology, 1, 1-9.

[31] Ellouze, M., et al. (2008) Detoxification of Tunisian Landfill Leachates by Selected Fungi. Journal of Hazardous Materials, 150, 642-648. https://doi.org/10.1016/j.jhazmat.2007.05.013

[32] Chang, B.-V. and Chang, Y.-M., (2014) Biodegradation of Toxic Chemicals by Pleurotus eryngii in Submerged Fermentation and Solid-State Fermentation. Journal of Microbiology, Immunology and Infection, In Press, 1-7.

[33] Gomes, E., et al. (2009) Ligninases Production by Basidiomycetes Strains on Lignocellulosic Agricultural Residues and Their Application in the Decolorization of Synthetic Dyes. Brazilian Journal of Microbiology, 40, 31-39.

https://doi.org/10.1590/S1517-83822009000100005

[34] Dinis, M.J., et al. (2009) Modification of Wheat Straw Lignin by Solid State Fermentation with White-Rot Fungi. Bioresource Technology, 100, 4829-4835. https://doi.org/10.1016/j.biortech.2009.04.036

[35] Thiribhuvanamala, G., et al. (2017) Induction of Lignolytic Enzyme Activities in Different Agro Residues by the White Rot Fungi, Pleurotus Sajar-Caju. International Journal of Chemical Studies, 5, 89-94.

[36] Mishra, V., et al. (2017) Enhancement in Multiple Lignolytic Enzymes Production for Optimized Lignin Degradation and Selectivity in Fungal Pretreatment of Sweet Sorghum Bagasse. Bioresource Technology, 236, 49-59.

https://doi.org/10.1016/j.biortech.2017.03.148

[37] Bilal, M. and Asgher, M. (2016) Biodegration of Agrowaste by Lingocellulolytic Activity of Oyster Mushroom, Pleurotus Sapidus. Journal of the National Science Foundation of Sri Lanka, 44, 399-407. https://doi.org/10.4038/jnsfsr.v44i4.8022

[38] Irbe, I., et al. (2014) Lignocellulolytic Activity of Coniophora puteana and Trametes versicolor in Fermentation of Wheat Bran and Decay of Hydrothermally Modified Hardwoods. International Biodeterioration \& Biodegradation, 86, 71-78. 
https://doi.org/10.1016/j.ibiod.2013.06.027

[39] Niebisch, C.H. (2009) Biodegradation of Ramazol Blye Dye by Lentinus crinitus, Lepista sordida e Hydnopolyporus fimbriatus. Master's Thesis, Universidade Federal do Paraná, Curitiba.

\section{Scientific Research Publishing}

Submit or recommend next manuscript to SCIRP and we will provide best service for you:

Accepting pre-submission inquiries through Email, Facebook, LinkedIn, Twitter, etc. A wide selection of journals (inclusive of 9 subjects, more than 200 journals)

Providing 24-hour high-quality service

User-friendly online submission system

Fair and swift peer-review system

Efficient typesetting and proofreading procedure

Display of the result of downloads and visits, as well as the number of cited articles Maximum dissemination of your research work

Submit your manuscript at: http://papersubmission.scirp.org/

Or contact abb@scirp.org 